\title{
New Zealand's Experiment in Pricing Access to Essential Facilities
}

\author{
Mike Ross
}

$\mathrm{O}$ ne of the most difficult issues in the reform of public utilities is how to secure access by private producers to essential facilities that they do not own. The legal battle between Telecom New Zealand and Clear Communications, finally resolved in 1995, has attracted widespread interest by illuminating many of the economic and legal principles at stake in this area. It also highligits the need for certain legal decisions to be informed by economic knowledge.

In September 1990, the Telecom Corporation of New Zealand was privatised. A consortium that included two American companies, Ameritech Corporation and Bell Atlantic Corporation, paid a price of NZ\$4.25 billion. Telecom enjoys a major commercial advantage through its ownership of local telephone networks, the 'public switched telecommunications network' (PSTN). This is an essential facility that cannot be duplicated easily.

Since March 1991, Clear Communications, a rival telecommunication company, has been negotiating with Telecom over charges for access to Telecom's PSTN. As competitors have no statutory right of connection to Telecom's PSTN, interconnection is a matter of negotiation and agreement. There is no independent body to resolve the position should negotiating parties fail to reach agreement, and the New Zealand government has imposed no industry-specific regulation on Telecom. Behaviour in the market is governed by the general law: the Commerce Act 1986 (so-called 'light-handed regulation'). In particular, Section 36 of the Commerce Act prohibits any person who has a dominant position in the market from using that dominant position for an anti-competitive purpose.

Long-running litigation between Clear and Telecom over fees payable by Clear to access the PSTN elicited sharply contrasting views on the role of the courts in deciding market pricing issues. On one side was the view that Telecom was entitled to a reasonable return on its investment in the telecommunications network. On the other side was the 'efficient component pricing' Baumol-Willig rule, under which Telecom could charge Clear no more for access than Telecom would charge itself for access. (The 'Baumol-Willig rule' is a convenient phrase used to summarise the expert evidence given in support of Telecom by the two eminent American economists, Professors William Baumol and Robert Willig.)

\section{The Decision}

New Zealand's highest court, the Privy Council, applied the Baumol-Willig rule as follows: 
Telecom would be acting uncompetitively if it refused to permit Clear to interconnect with Telecom's network. But it is not acting uncompetitively in charging its opportunity cost since that is what it would have charged in a fully competitive market. ${ }^{1}$

The Privy Council ruled that Telecom would not be misusing its dominant market position (its ownership of the essential facility) if it allowed Clear to interconnect on payment of the average incremental cost to Telecom of supplying the PSTN plus the revenue Telecom would have received if it supplied the service to Clear customers less the cost saved by Telecom by reason of Clear providing and handling any calls to or from a Clear customer over the sector from the interconnection with Telecom's network and the Clear customer (and vice versa). On this basis, Telecom and Clear would compete on the same terms in providing services through their respective 'local loops' - the connection of customers to the PSTN. Should Clear be the more efficient provider of this service, it would be able to charge less for calls. It is claimed that this competition will force Telecom to cut its charges, thereby reducing its opportunity cost and consequently reducing the access levy charged to Clear. This competition should, over time, reduce any monopoly rents Telecom enjoys through its ownership of the essential facility.

\section{The Negotiations}

When negotiations between Clear and Telecom opened over the terms of an interconnection agreement, Clear proposed: that interchange of calls between itself and Telecom be free (with adjustments to account for any imbalance in calls from one network to the other); that the costs of the physical interconnection be shared equally; and that Clear not be required to contribute to the subsidy to residential customers arising from the 'Kiwi share' obligation. When Telecom was privatised, the New Zealand government guaranteed the continuation of the existing crosssubsidy between commercial and residential users by retaining a single share: the 'Kiwi share'. Telecom's constitution requires the consent of the Kiwi shareholder to any change in pricing that may increase the standard line rental for residential users in rural areas above that charged to urban residential users; or increase charges to residential users in real terms (i.e. in excess of increases in the Consumer Price Index); or introduce a charge per call for residential users. This gives government a right of veto over any Telecom practices that might adversely affect residential users.

Telecom dismissed Clear's opening offer as an attempt to free ride on the Telecom network by avoiding any contribution to the costs of maintaining the network. It alleged that Clear sought to 'cherry pick' the rich revenue stream available to operators providing a telephone service to commercial users in the central busi-

\footnotetext{
${ }^{1}$ Telecom Corporation of New Zealand Ltd v Clear Communications [1995] 1 NZLR 385, 406.
} 
ness district of major cities. ${ }^{2}$ Further negotiations proved inconclusive. Clear sued Telecom, alleging that Telecom was in breach of s.36 of the Commerce Act 1986 by using its dominant position for an anti-competitive purpose.

\section{The Litigation}

The first round of litigation was heard in the New Zealand High Court before Justice Ellis and Professor Maureen Brunt, an Australian economist. Evidence was heard over 38 days (four of those days in Los Angeles as Professor Baumol was too ill to travel to New Zealand to give evidence). The High Court judgment, which runs to 100 pages, defies easy precis.

The New Zealand High Court adopted the Baumol-Willig rule. The rule draws on what Professor Alfred Kahn (who gave expert evidence on behalf of Telecom) called 'the principle of competitive parity'. Application of this principle concentrated not on the absolute level of Telecom charges, but rather on whether Telecom was seeking to charge Clear more for the service provided to Clear than it charged its own customers for the same component of its own services. It was conceded that the Baumol-Willig approach enabled Telecom to secure, by way of payment from Clear, any monopoly rents present in its existing charges; but the High Court ruled that it had not been established in evidence that Telecom was currently earning monopoly rents. On the court's interpretation, the Baumol-Willig rule hypothesises that where Clear provides a more efficient service to its customers, Telecom will be forced to reduce its prices, thereby diminishing its opportunity cost and so diminishing the amount of the access levy charged Clear. This process of forcing down the price will continue until any element of monopoly price is 'competed out' of Telecom's charges. The High Court urged Clear and Telecom to resolve their differences using the Baumol-Willig model. Clear appealed the decision.

The New Zealand Court of Appeal unanimously allowed the appeal. The court relied on legal analysis, not economic principle, when discussing the application of the Commerce Act 1986, approaching the case as a question of statutory interpretation. The court was dismissive of the opportunity-cost approach. The President of the Court of Appeal, Justice Cooke, summarised the position:

Telecom is entitled to a fair commercial return for granting Clear use of the network assets ... This means that opportunity costs should be ignored and the charge fixed on the basis of what a network owner not in competition for the custom of subscribers could reasonably charge for use of its facilities. $^{3}$

\footnotetext{
2 It should be noted that in May 1991, Clear and Telecom did successfully negotiate an interconnection agreement enabling Clear to operate a toll service in competition with Telecom Clear now has a market share of some 15 per cent in the tolls market

${ }^{3}$ Clear Communications Ldd v Telecom Corporation (1993) 4 NZBLC 103,340, $103,344$.
} 
The Court of Appeal ruled that Telecom's negotiating stance did constitute an anti-competitive practice in breach of the Commerce Act. It awarded no damages to Clear, but ordered the parties to resume negotiations. Both parties appealed to the Privy Council: Telecom appealing against the finding that it was in breach of s.36 of the Commerce Act 1986, and Clear appealing against the finding that it had suffered no loss and was not entitled to damages.

The Privy Council found unanimously in favour of Telecom. The Court of Appeal was reversed, and the High Court reasoning reinstated. The Privy Council stated that 'a monopolist was entitled, like everyone else, to compete with its competitors'.4 It also said that monopolists, who under the Commerce Act 1986 face fines of up to NZ\$5m for anti-competitive behaviour, were entitled to some judicial direction as to what was likely to be construed as anti-competitive behaviour. The Privy Council ruled that a person in a dominant position does not act anticompetitively by acting as if in a fully competitive market. Opportunity costs are relevant.

. . . in a fully competitive market, someone $(X)$ earning a net profit of, say, $\$ 1000$ per month from the use of one of its assets is not going to provide the use of that asset to another at a figure less than $\$ 1000$ per month. In a competitive market the would-be buyer might be able to obtain the use of a similar asset from another and possibly at a lower price. But X will not be acting uncompetitively if he refuses to deal at a figure less than that which he is currently receiving. ${ }^{5}$

Telecom was not acting uncompetitively in charging its opportunity cost, since that is what it would have charged in a fully competitive market.

\section{The Implications}

This New Zealand litigation has its supporters and detractors. The latter have been the more voluble. Lawyers and economists who do not support the Baumol-Willig hypothesis and its application in this case regard the outcome as blatantly anticompetitive. They are offended by the apparent ease with which Telecom can entrench (temporarily) any existing monopoly rents. Nevertheless, the purchasers of Telecom on privatisation paid a substantial premium. One of the assets they purchased was an essential facility: the PSTN. Those with a concern for property rights question whether Telecom should be forced to give up this benefit without compensation.

The Baumol-Willig approach is not without its practical difficulties. The rule does not fix the terms for interconnection, but establishes a methodology for determining a price. It requires agreement as to the extent of Telecom's opportunity

\footnotetext{
4 Telecom Corporation of New Zealand LAd v Clear Communications [1995] 1 NZLR 402.

5 Id. 405-6.
} 
cost in losing custom to Clear. This cost is not and will not be static: regular reviews will be required, as with any long-term supply contract.

The litigation has provided an unusual example of legal reasoning derived from economic principle. To many lawyers, unfamiliar with economic concepts, the High Court's reasoning is incomprehensible. Generally, lawyers seldom feel the need to understand economic theory or to consider the economic impact of their jurisprudence. This litigation has forced the New Zealand legal profession to recognise that economic principle has a place in deciding legal questions.

Mike Ross is Senior Lecturer in Commercial Law at the University of Auckland. 